\title{
Cost Analysis of Potentially Causes the Cost Overrun Occur in Housing Projects at Malang City, East Java, Indonesia
}

\author{
Sumardi \\ Department of Civil Engineering, State Polytechnic of Malang
}

Doi:10.5901/mjss.2016.v7n5p75

\begin{abstract}
This study aims to determine: 1) The most dominant factor in the cause of the overrun cost housing project in the Malang city. 2) What should be done to minimize cost overruns due to to these factors. Samples were some 30 personnel of Techniques Estimation, from 15 Developers who are members of the members of REI (Real Estate) Malang city. This study uses survey techniques by distributing questionnaires to technicians developers in Malang City. Data were analyzed using descriptive statistics methods. Based on the analysis results obtained: 1) The dominant factor causing cost overruns are: risk factors on the location and construction are not considered, the supervision was not done properly, Theft material, the influence of extreme weather, high bank interest rates. 2) Solution to minimize swelling due to the dominant factor is the implementer before starting the job should be to analyze the concept and study of economic and attention to the environmental impacts.
\end{abstract}

Keywords: a cost overrun, housing projects, risk

\section{Introduction}

In the implementation of construction projects, the cost factor is a major consideration because of cost concerns the large amount of investment that should be instilled taskmaster at risk of failure. Therefore, the cost of the project needs to be managed properly so that the possibility of cost overrun can be minimized. Determining the cost of a project involving a combined circuit and related parties and is the most important of a project in accordance with the expected all parties involved in each project completion can be achieved in accordance with the specification within the prescribed schedule and within the budget plan that can be set.

The housing project is one of the construction projects are unique and complex, high-risk and an integration of various disciplines so many factors that can lead to swelling costs (cost overrun). The larger the project the greater the potential for cost overruns (Santosa, 2009). On the implementation of construction projects found many experience swelling in terms of cost and time. Even mentioned that eight of the ten projects have swelling (Nurhayati, 2010), moreover the weather conditions in Malang City is currently uncertain enabling the cost overrun. The project will be managed properly in accordance with our cost / budget has been planned, on time and within specifications (Husen, 2008).

The economic development of the ups and downs lately resulted in raw material prices and the purchasing power of the people changed. This gives effect to the housing contractors in determining the price and volume of the house. So the information material and labor prices prevailing at the time the project is implemented must be complete and accurate. Changes in home design is also one of the factors delayed the work, resulting in increased costs. Focused on the things above, the author would like to discuss more about the factors that cause swelling of the cost (cost overrun) in housing projects (Ervianto dan Wulfram, 2005; Syahroni, 2006; Suyatno, 2010).

\section{Material and Methods}

\subsection{Research variable}

In this study, carried out literature studies to determine the variables to be studied. The research variables here are the factors that cause cost overrun on a housing project in Malang. The concept and design of the study variables items obtained from theoretical study. These variables are translated into indicators. Based on these indicators, the next will be elaborated in the form of questionnaires (Riduwan, 2003). 
Table 1: Variable and Item Questions

\begin{tabular}{|c|c|}
\hline Variable & Variable Operationalization \\
\hline $\begin{array}{l}\text { The factors that cause of cost } \\
\text { overrun }\end{array}$ & $\begin{array}{l}\text { 1. Pre-Planning } \\
\text { a. The choice of location is less strategic } \\
\text { b. Land purchased turned out to be problematic } \\
\text { 2. Planning } \\
\text { a. Data and information project less complete } \\
\text { b. Do not take into account the effects of inflation and escalation } \\
\text { c. Do not pay attention to the risk factors on the location and } \\
\text { d. Insccuracy cost estimate } \\
\text { e. Do not take into account the tactical environment fund } \\
\text { f. Scope of work is not well-defined } \\
\text { 3. Implementation } \\
\text { a. Too much repetition of work because of poor quality } \\
\text { b. Too many projects are handled in the same time } \\
\text { c. Supervision was not done properly } \\
\text { d. The project manager is less competent } \\
\text { e. Disputes in the project } \\
\text { f. The complaints of the user } \\
\text { 4. Resources Coordination } \\
\text { a. Late / lack of material time execution } \\
\text { b. Poor quality control material } \\
\text { c. Theft material } \\
\text { d. Mistakes in the use of materials } \\
\text { e. Poor quality of labor } \\
\text { f. Labor strike } \\
\text { g. Utilization of labor is not optimal } \\
\text { h. The high price of equipment rental } \\
\text { 5. Control } \\
\text { Poor financial controls } \\
\text { The high interest rates on bank loans } \\
\text { The influence of extreme weather } \\
\text { Disturbed state system / of the riot }\end{array}$ \\
\hline
\end{tabular}

\subsection{Making Questionnaire}

In making the research questionnaire, in the plan, there are two sections in the questionnaire. The first section contains general information consisting of data of respondents and project information. Respondent data and project information explaining personal data of respondents and the company, the work experience in the implementation of the construction of housing projects especially appropriate to the scope of the study. The second part is a frequency table of the factors causing the cost overrun that contains the frequency of occurrence of the factors that cause cost overruns on housing projects over the years. The scale used has a range of 1-5 (never happened - very often occur). Within this questionnaire respondents were asked to fill out a frequency intensity value that occurred during the implementation phase of construction projects. Values intensity is frequency value based on the scale that occurred at a step by the experience and events experienced by respondents.

\subsection{Variable measurement scale}

To obtain quantitative data on the charging interpretation problems in the research instrument, the scale of measurement variables created with ranges of 1 to 5 , to measure the frequency as follows:

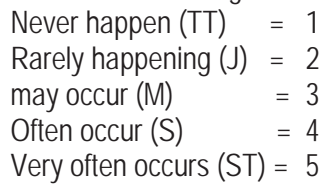


Table 2: Parameter the Rate of Respondents

\begin{tabular}{|l|l|}
\hline Parameter & Description \\
\hline TT & $\begin{array}{l}\text { This case never happened. } \\
\text { Possibility is 0\% in each project. }\end{array}$ \\
\hline $\mathrm{J}$ & $\begin{array}{l}\text { This case are rare } \\
\text { Possible occurred between } 1 \%-30 \% \text { in each project. }\end{array}$ \\
\hline M & $\begin{array}{l}\text { This case may occur at a time } \\
\text { The possibility of between } 30 \%-50 \% \text { in each project. }\end{array}$ \\
\hline S & $\begin{array}{l}\text { This case never happened and may happen again } \\
\text { The possibility of between } 50 \%-70 \% \text { in each project. }\end{array}$ \\
\hline ST & $\begin{array}{l}\text { This case are very often occur in various circumstances. } \\
\text { The possibility of more than } 70 \% \text { in each project. }\end{array}$ \\
\hline
\end{tabular}

\subsection{Research population}

a. Research Location: The research was conducted on the developer housing of DPD REI members based in Malang

b. Research population: The population of this research are the developer housing of DPD REI members based in Malang

\subsection{Determination of Number of Samples}

The study was conducted on the developer housing of DPD REI members based in Malang whose population was 36 . A sample of respondents in this study is the developer ages 25 to 28 years both men and woman who serves as a field manager. The determination of the samples in this study using Slovin formula (in Umar, 2008) as follows:

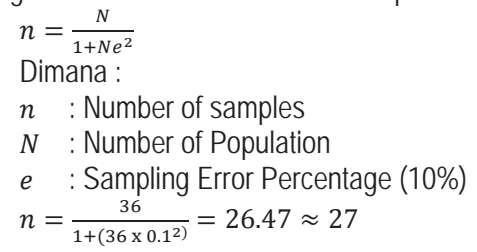

\subsection{Data collection methods}

In this study requires two types of data, primary data and secondary data. The data obtained in the study conducted using the method of observation (observation), questionnaires and interviews. Observation is a complex process, a process that is composed of a variety of biological and psychological processes. Interviewing is a method of data collection that must be taken by a researcher when researchers want to conduct a preliminary study to find a problem that must be investigated and to know things about the respondents deeper. A questionnaire is a research instrument that closed-ended and open-ended questions consisting of a series of questions and other prompts for the purpose of gathering information from respondents. Questionnaire in the present study be closed is by asking closed questions using a Likert scale (Sugiono, 2011).

\subsubsection{Primary Data Collection}

Primary data were collected by distributing questionnaires and interviews with respondents who are considered worthy enough to provide data. To obtain data consistent with the intent and purpose of the study, the respondents will be accompanied by minimal or no explanation of how to fill. Respondents must be completely ascertained to understand the topic and earnestly keep the truth of perception.

\subsubsection{Secondary Data Collection}

Secondary data were obtained from the literatures, journals, or based on the experience of those who have or are involved in the work of the implementation of housing projects. 


\subsection{Validity and Reliability Test}

To determine whether or not the measuring instruments used in data collection, researchers will always pay attention to two important issues are reliability and validity. Validity is a measure that indicates the levels of legality or validity of an instrument. A valid instrument has high validity. Instead invalid instrument means having a low validity. Testing the validity and reliability of the testing process item questions in the questionnaire are valid (legitimate) and reliably. When it is valid and realible, means grains of these questions can already be used for deeper analysis (Arikunto, 2006).

\subsection{Data analysis}

Processing of the data to resolve problems in research as mentioned in the formulation of the problem in the introduction using descriptive analysis. This analysis is useful to get information that is descriptive of the study variables. Descriptive statistics intended to analyze the collected data as it is without intending to make a general conclusion or generalization. So this analysis is supportive subsequent data analysis (Cooper and Schindler, 2006). Data and results are tabulated in Table frequency with the help of SPSS14.0 program and Microsoft Excel for Windows.

\section{Results and Discussion}

\subsection{The frequency of occurrence of cost overrun due to Pre-Planning Factors}

Based on the analysis of data, obtained a description that the cost overrun is due to of pre-planning factors are as follows:

Table 3: The frequency of occurrence of cost overrun due to Pre-Planning Factors

\begin{tabular}{|c|c|c|c|c|c|c|}
\hline \multirow{3}{*}{ No } & \multicolumn{6}{|c|}{ Cost Overrun of Pre-Planning Factors } \\
\hline & \multirow{2}{*}{ Ratings scale } & \multirow{2}{*}{ Score } & \multicolumn{2}{|r|}{ A1 } & \multicolumn{2}{|r|}{$\mathrm{A} 2$} \\
\hline & & & $\Sigma$ & $\%$ & $\Sigma$ & $\%$ \\
\hline 1 & Never happen & 1 & 2 & $6.67 \%$ & 2 & $6.67 \%$ \\
\hline 2 & Rarely happening & 2 & 10 & $33.33 \%$ & 11 & $36.67 \%$ \\
\hline 3 & May occur & 3 & 3 & $10.00 \%$ & 2 & $6.67 \%$ \\
\hline 4 & Often occur & 4 & 11 & $36.67 \%$ & 10 & $33.33 \%$ \\
\hline 5 & Very often occurs & 5 & 4 & $13.33 \%$ & 5 & $16.67 \%$ \\
\hline \multicolumn{3}{|c|}{$\Sigma$} & 30 & $100 \%$ & 30 & $100 \%$ \\
\hline \multicolumn{3}{|c|}{ Average Score } & \multicolumn{2}{|c|}{3,17} & \multicolumn{2}{|r|}{3,17} \\
\hline
\end{tabular}

Description:

$\mathrm{A} 1=$ Choice of location less strategic

$\mathrm{A} 2$ = Land purchased turned out to be problematic

From the above table it is known that less strategic location selection and land purchased problematic equally likely lead to cost overrun.

\subsection{The Frequency of Occurrence of Cost Overrun Due to Pre-Planning Factors}

Based on the analysis of data, obtained a description that the cost overrun resulting planning factor are as follows.

Table 4: The Frequency of Occurrence of Cost Overrun Due to Pre-Planning Factors

\begin{tabular}{|c|c|c|c|c|c|c|c|c|c|c|c|c|c|c|}
\hline \multirow{3}{*}{ No } & \multicolumn{14}{|c|}{ Cost Overrun Due to Pre-Planning Factors } \\
\hline & \multirow{2}{*}{ Ratings Scale } & \multirow{2}{*}{ Score } & \multicolumn{2}{|c|}{ B1 } & \multicolumn{2}{|r|}{ B2 } & \multicolumn{2}{|c|}{ B3 } & \multicolumn{2}{|c|}{ B4 } & \multicolumn{2}{|r|}{ B5 } & \multicolumn{2}{|r|}{ B6 } \\
\hline & & & $\Sigma$ & $\%$ & $\Sigma$ & $\%$ & $\Sigma$ & $\%$ & $\Sigma$ & $\%$ & $\Sigma$ & $\%$ & $\Sigma$ & $\%$ \\
\hline 1 & Never $\mathrm{H}$ & 1 & 1 & $3,33 \%$ & 0 & $0,00 \%$ & 1 & $3,33 \%$ & 2 & $6,67 \%$ & 2 & $6,67 \%$ & 1 & $3,33 \%$ \\
\hline 2 & Rarely Happening & 2 & 9 & $30,00 \%$ & 8 & $26,67 \%$ & 8 & $26,67 \%$ & 10 & $33,33 \%$ & 9 & $30,00 \%$ & 10 & $33,33 \%$ \\
\hline 3 & May Occur & 3 & 11 & $36,67 \%$ & 8 & $26,67 \%$ & 3 & $10,00 \%$ & 2 & $6,67 \%$ & 4 & $13,33 \%$ & 6 & $20,00 \%$ \\
\hline 4 & Often Occur & 4 & 2 & $6,67 \%$ & 8 & $26,67 \%$ & 9 & $30,00 \%$ & 13 & $43,33 \%$ & 12 & $40,00 \%$ & 9 & $30,00 \%$ \\
\hline
\end{tabular}




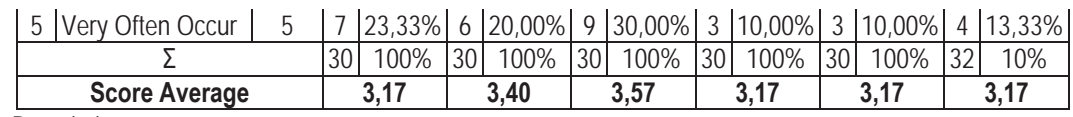

Description:

$\mathrm{B} 1=$ Data and information project less complete

$\mathrm{B} 2$ = Do not take into account the effects of inflation and escalation

$\mathrm{B} 3=$ Do not pay attention to the risk factors on the location and construction

B4 = Inaccuracy cost estimate

$\mathrm{B} 5=$ Do not take into account the tactical environment fund

$\mathrm{B} 6=$ Scope of work is not well-defined

Based on Table 4 unknown do not take into account the risk factors on the location and construction have most likely caused cost overrun than other planning factors with the respondents' assessment $3.33 \%$ of respondents chose never happened, $26.67 \%$ of respondents chose rare, $10 \%$ of respondents chose the case maybe occur, $30 \%$ of respondents choose often occur, $30 \%$ of respondents are very often occur.

\subsection{The Frequency of Occurrence of Cost Overrun Due to Implementation Factors}

Based on the analysis of data, obtained a description that the overrun costs resulting from the implementation factor are as follows.

Table 5: The Frequency of Occurrence of Cost Overrun Due to Implementation Factors

\begin{tabular}{|c|c|c|c|c|c|c|c|c|c|c|c|c|c|c|}
\hline \multirow{3}{*}{$\mathrm{N}$} & \multicolumn{14}{|c|}{ Due to Implementation Factors } \\
\hline & \multirow[t]{2}{*}{ Ratings Scale } & \multirow[t]{2}{*}{ Score } & \multicolumn{2}{|r|}{$\mathrm{C} 1$} & \multicolumn{2}{|r|}{$\mathrm{C} 2$} & \multicolumn{2}{|r|}{ C3 } & \multicolumn{2}{|r|}{ C4 } & \multicolumn{2}{|r|}{$\mathrm{C} 5$} & \multicolumn{2}{|r|}{ C6 } \\
\hline & & & $\Sigma$ & $\%$ & $\Sigma$ & $\%$ & $\Sigma$ & $\%$ & $\Sigma$ & $\%$ & $\Sigma$ & $\%$ & $\Sigma$ & $\%$ \\
\hline 1 & Vever Happen & 1 & 0 & $0,00 \%$ & 3 &, $00 \%$ & 0 & $0,00 \%$ & 0 & $0,00 \%$ & 2 & $6,67 \%$ & 2 & $67 \%$ \\
\hline & Rar & 2 & 12 & 40,0 & 6 & 20,0 & 6 & $20,00 \%$ & 113 & $\%$ & 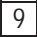 & 30,0 & 9 & 30 \\
\hline & May O & 3 & 9 & 30,0 & 6 & $20,00 \%$ & 8 & $26,67 \%$ & 62 & $20,00 \%$ & 4 & 13, & 5 & 16,670 \\
\hline 4 & cur & 4 & 4 & $13,33 \%$ & 13 & $43,33 \%$ & 10 & $33,33 \%$ & 103 & $33,33 \%$ & 12 & $40,00 \%$ & 10 & $33,33 \%$ \\
\hline 5 & Very Often Occur & 5 & 5 & $16,67 \%$ & 2 & $6,67 \%$ & 6 & $20,00 \%$ & 3 & $10,00 \%$ & 3 & $10,00 \%$ & 4 & $13,33 \%$ \\
\hline \multicolumn{3}{|c|}{$\Sigma$} & 30 & $100 \%$ & 30 & $100 \%$ & 30 & $100 \%$ & 30 & $100 \%$ & 30 & $100 \%$ & 30 & $100 \%$ \\
\hline \multicolumn{3}{|c|}{ Score Average } & & 3,07 & & 3,17 & & 3,53 & & 3,17 & & 3,17 & & 3,17 \\
\hline
\end{tabular}

Description:

$\mathrm{C1}=$ Too much repetition of work because of poor quality

$\mathrm{C} 2$ = Too many projects are handled in the same time

$\mathrm{C} 3$ = Supervision was not done properly

$\mathrm{C} 4=$ The project manager is less competent

$\mathrm{C} 5=$ Disputes in the project

C6 = The complaints of the user

Based on Table 5 has known that the supervision is not done well has most likely cause of overrun costs than other execution factors by respondents rating $0 \%$ of respondents chose never happened, $20 \%$ of respondents chose rarely happening, $26.67 \%$ of respondents chose the case may be occur, $33.33 \%$ of respondents choose often occur, $20 \%$ of respondents are very often occurs.

\subsection{The Frequency of Occurrence of Cost Overrun Due to Resource Coordination Factor}

Based on the analysis of data, obtained a description that the overrun costs resulting from resource coordination factor is as follows.

Table 6: The Frequency of Occurrence of Cost Overrun Due to Resource Coordination Factor

\begin{tabular}{|c|c|c|c|c|c|c|c|c|c|}
\hline \multirow{3}{*}{ No Cost Overrun Due to Resource Coordination Factor } \\
\cline { 2 - 10 } & \multirow{2}{*}{ Ratings Scale } & \multirow{2}{*}{ Score } & \multicolumn{2}{|c|}{ D1 } & \multicolumn{2}{|c|}{ D2 } & \multicolumn{2}{|c|}{ D3 } & \multicolumn{2}{c|}{ D4 } \\
\cline { 4 - 10 } & & $\Sigma$ & $\%$ & $\Sigma$ & $\%$ & $\Sigma$ \\
\hline
\end{tabular}




\begin{tabular}{|c|c|c|c|c|c|c|c|c|c|c|}
\hline 1 & Never Happen & 1 & 2 & $6,67 \%$ & 2 & $6,67 \%$ & 0 & $0,00 \%$ & 2 & $6,67 \%$ \\
\hline 2 & Rarely Happening & 2 & 10 & $33,33 \%$ & 9 & $30,00 \%$ & 9 & $30,00 \%$ & 7 & $23,33 \%$ \\
\hline 3 & May Occur & 3 & 4 & $13,33 \%$ & 4 & $13,33 \%$ & 6 & $20,00 \%$ & 9 & $30,00 \%$ \\
\hline 4 & Often Occur & 4 & 9 & $30,00 \%$ & 12 & $40,00 \%$ & 6 & $20,00 \%$ & 9 & $30,00 \%$ \\
\hline 5 & Very Often Occur & 5 & 5 & $16,67 \%$ & 3 & $10,00 \%$ & 9 & $30,00 \%$ & 3 & $10,00 \%$ \\
\hline \multicolumn{3}{|c|}{$\Sigma$} & 30 & $100 \%$ & 30 & $100 \%$ & 30 & $100 \%$ & 30 & $100 \%$ \\
\hline \multicolumn{3}{|c|}{ Score Average } & \multicolumn{2}{|r|}{3,17} & \multicolumn{2}{|r|}{3,17} & \multicolumn{2}{|r|}{3,50} & \multicolumn{2}{|r|}{3,13} \\
\hline \multirow[b]{2}{*}{ No } & \multirow{2}{*}{ Ratings Scale } & \multirow{2}{*}{ Score } & \multicolumn{2}{|r|}{ D5 } & \multicolumn{2}{|r|}{ D6 } & \multicolumn{2}{|r|}{ D7 } & \multicolumn{2}{|r|}{ D8 } \\
\hline & & & $\Sigma$ & $\%$ & $\Sigma$ & $\%$ & $\Sigma$ & $\%$ & $\Sigma$ & $\%$ \\
\hline 1 & Never Happen & 1 & 1 & $3,33 \%$ & 1 & $3,33 \%$ & 1 & $3,33 \%$ & 1 & $3,33 \%$ \\
\hline 2 & Rarely Happening & 2 & 12 & $40,00 \%$ & 6 & $20,00 \%$ & 11 & $36,67 \%$ & 6 & $20,00 \%$ \\
\hline 3 & May Occur & 3 & 5 & $16,67 \%$ & 11 & $36,67 \%$ & 9 & $30,00 \%$ & 13 & $43,33 \%$ \\
\hline 4 & Often Occur & 4 & 5 & $16,67 \%$ & 11 & $36,67 \%$ & 4 & $13,33 \%$ & 7 & $23,33 \%$ \\
\hline 5 & Very Often Occur & 5 & 7 & $23,33 \%$ & 1 & $3,33 \%$ & 5 & $16,67 \%$ & 3 & $10,00 \%$ \\
\hline \multicolumn{3}{|c|}{$\Sigma$} & 30 & $100 \%$ & 30 & $100 \%$ & 30 & $100 \%$ & 30 & $100 \%$ \\
\hline \multicolumn{3}{|c|}{ Score Average } & \multicolumn{2}{|r|}{3,17} & \multicolumn{2}{|c|}{3,17} & \multicolumn{2}{|r|}{3,03} & \multicolumn{2}{|r|}{3,17} \\
\hline
\end{tabular}

\section{Description:}

D1 = Late / lack of material time execution

D2 = Poor quality control material

D3 = Theft material

D4 = Mistakes in the use of materials

D5 = Poor quality of labor

D6 = Labor strike

D7 = Utilization of labor is not optimal

D8 $=$ The high price of equipment rental

Based on Table 6 has known that the theft of material have most likely led to the overrun cost factor than other resource coordination with respondents rating $0 \%$ of respondents chose never happened, $30 \%$ of respondents chose rarely happening, $20 \%$ of respondents chose the case may be occur, $20 \%$ of respondents choose often occur, $30 \%$ of respondents are very often occurs.

\subsection{The Frequency of Occurrence of Cost Overrun Due to Control Factor}

Based on the analysis of data, obtained a description that the cost overrun is due to control factors are as follows:

Table 7: The Frequency of Occurrence of Cost Overrun Due to Control Factor

\begin{tabular}{|c|c|c|c|c|c|c|c|c|c|c|}
\hline \multirow{3}{*}{ No } & \multicolumn{10}{|c|}{ Cost Overrun Due to Control Factor } \\
\hline & \multirow{2}{*}{ Ratings Scale } & \multirow{2}{*}{ Skor } & \multicolumn{2}{|r|}{ E1 } & \multicolumn{2}{|r|}{ E2 } & \multicolumn{2}{|r|}{ E3 } & \multicolumn{2}{|r|}{ E4 } \\
\hline & & & $\Sigma$ & $\%$ & $\Sigma$ & $\%$ & $\Sigma$ & $\%$ & $\Sigma$ & $\%$ \\
\hline 1 & Never Happen & 1 & 0 & $0,00 \%$ & 0 & $0,00 \%$ & 0 & $0,00 \%$ & 1 & $3,33 \%$ \\
\hline 2 & Rarely Happening & 2 & 8 & $26,67 \%$ & 13 & $43,33 \%$ & 12 & $40,00 \%$ & 6 & $20,00 \%$ \\
\hline 3 & May Occur & 3 & 4 & $13,33 \%$ & 6 & $20,00 \%$ & 9 & $30,00 \%$ & 9 & $30,00 \%$ \\
\hline 4 & Often Occur & 4 & 13 & $43,33 \%$ & 5 & $16,67 \%$ & 3 & $10,00 \%$ & 6 & $20,00 \%$ \\
\hline 5 & Very Often Occur & 5 & 5 & $16,67 \%$ & 6 & $20,00 \%$ & 6 & $20,00 \%$ & 8 & $26,67 \%$ \\
\hline \multicolumn{3}{|c|}{$\Sigma$} & 30 & $100 \%$ & 30 & $100 \%$ & 30 & $100 \%$ & 30 & $100 \%$ \\
\hline \multicolumn{3}{|c|}{ Score Average } & \multicolumn{2}{|r|}{3,50} & \multicolumn{2}{|r|}{3,13} & \multicolumn{2}{|r|}{3,10} & \multicolumn{2}{|r|}{3,47} \\
\hline
\end{tabular}

Description:

E1 = The influence of extreme weather

E2 = Disturbed state system / of the riot

E3 $=$ Poor financial controls

E4 = The high interest rates on bank loans

From the above table is known of the effects of extreme weather that are most likely to have caused the overrun cost factor than the control / other controls with respondents rating $0 \%$ of respondents chose never happened, $26.67 \%$ of respondents chose rarely happening, $13.33 \%$ of respondents chose the case may be occur, $43.33 \%$ of respondents choose often occur, $16.67 \%$ of respondents are very often occurs. 


\subsection{Determining Dominant factors}

The following are the average respondent's assessment of the causes of the overrun. In the interpretation of the average frequency of factors causing cost overruns be calculated as follows:

Minimum possible value $=1$

Maximum possible value $=5$

Range $=$ Maximum value - Minimum value

$=5-1$

$=4$

Long interval $=$ Range: Many categories

$$
\begin{aligned}
& =4: 5 \\
& =0,8
\end{aligned}
$$

With a length of interval above, it may be possible to interpret the category average frequency of the factors that cause an overrun as follows:

Table 8: Interpretation Guidelines for the average frequency of the overrun cause

\begin{tabular}{|c|l|}
\hline Interval & Frequency of the overrun \\
\hline $1,00-1,80$ & Never happen \\
\hline $1,81-2,60$ & Rarely happening \\
\hline $2,61-3,40$ & May occur \\
\hline $3,41-4,20$ & Often occur \\
\hline $4,21-5,00$ & Very often occurs \\
\hline
\end{tabular}

After calculating the average of the frequency of occurrence of risks and losses caused to each of the factors causing the overrun, presented the following average values and the interpretation in the table below.

\begin{tabular}{|c|c|c|c|c|}
\hline No & Code & Factors causes cost overrun & Average Rating & Interpretation \\
\hline 1 & A1 & The choice of location is less strategic & 3.17 & May occur \\
\hline 2 & $\mathrm{~A} 2$ & Land purchased turned out to be problematic & 3.17 & May occur \\
\hline 3 & B1 & Data and information project less complete & 3.17 & May occur \\
\hline 4 & B2 & Do not take into account the effects of inflation and escalation & 3.37 & May occur \\
\hline 5 & B3 & Do not pay attention to the risk factors on the location and construction & 3.57 & Often occur \\
\hline 6 & B4 & Inaccuracy cost estimate & 3.17 & May occur \\
\hline 7 & B5 & Do not take into account the tactical environment fund & 3.17 & May occur \\
\hline 8 & B6 & Scope of work is not well-defined & 3.17 & May occur \\
\hline 9 & C1 & Too much repetition of work because of poor quality & 3.07 & May occur \\
\hline 10 & $\mathrm{C} 2$ & Too many projects are handled in the same time & 3.17 & May occur \\
\hline 11 & C3 & Supervision was not done properly & 3.53 & Often occur \\
\hline 12 & $\mathrm{C} 4$ & The project manager is less competent & 3.17 & May occur \\
\hline 13 & C5 & Disputes in the project & 3.17 & May occur \\
\hline 14 & $\mathrm{C} 6$ & The complaints of the user & 3.17 & May occur \\
\hline 15 & $\mathrm{D} 1$ & Late / lack of material time execution & 3.17 & May occur \\
\hline 16 & D2 & Poor quality control material & 3.17 & May occur \\
\hline 17 & D3 & Theft material & 3.50 & Often occur \\
\hline 18 & D4 & Mistakes in the use of materials & 3.13 & May occur \\
\hline 19 & D5 & Poor quality of labor & 3.17 & May occur \\
\hline 20 & D6 & Labor strike & 3.17 & May occur \\
\hline 21 & D7 & Utilization of labor is not optimal & 3.03 & May occur \\
\hline 22 & D8 & The high price of equipment rental & 3.17 & May occur \\
\hline 23 & E1 & The influence of extreme weather & 3.50 & Often occur \\
\hline 24 & E2 & Disturbed state system / of the riot & 3.13 & May occur \\
\hline 25 & E3 & Poor financial controls & 3.10 & May occur \\
\hline 26 & E4 & The high interest rates on bank loans & 3.47 & Often occur \\
\hline
\end{tabular}

Table 9: Recapitulation Average Frequency Causes Overrun and The Categories 
From the above table are known factors that often causes the cost overrun are as follows (Asiyanto, 2009; Dimyati dan Nurjaman, 2014). :

1. Risk Factors in the Location and Construction unnoticed

2. Supervision was not done properly

3. Material theft

4. The Influence of Weather Is Extreme

5. The high interest rates on bank loans

\subsection{Risk Factors in the Location and Construction unnoticed}

To minimize the risk of the executor before starting construction on the field should make an analysis of conception, engineering feasibility study report on the economic and environmental impact, so that implementers can anticipate things that are not desirable (Soeharto, 1995). It is also to facilitate the implementation of the work (Kerzner, 1992).

\subsection{Supervision was not done properly}

Supervisors is one of the factors that affect the continuity of the project in terms of both technical and economical. Implementing should choose an experienced and professional inspectors so that the failure of the project in terms of both technical and economical can be minimized.

\subsection{Material theft}

Theft in the project area can be caused by the executor less careful in the placement of materials and equipment, in addition to implementing less attention to the social environment around the site. Theft countermeasures can be anticipated by using labor and energy security of the citizens about the project. Thus the residents are expected to participate oversees and is responsible for the theft of materials.

\subsection{The Influence of Weather Is Extreme}

Changes in the weather was not good, at risk to the continuation of projects that can lead to cost overruns. This is made possible risks arising from the implementation time during high rainfall. The solution is to do the planning cycle-controlcorrection continuously, so due to irregularities it can be minimized and great difficulty to reach the target can be avoided (Soeharto, 1995).

\subsection{The high interest rates on bank loans}

The amount of the percentage of interest on bank loans can be fixed, but can also be changed. The level of interest is largely dependent on the money market. Lending policies often differ from one bank to another bank (Soeharto, 1995). Therefore, a comparative study should be conducted to determine the source of funding.

\section{Conclusion}

Based on the analysis of research data can be concluded, the determining of dominant factors that causes the cost overrun are unnoticed risk factors in the location and construction, supervision was not done properly, material theft, the influence of weather is extreme and the high interest rates on bank loans. The solution provided to minimize the occurrence of overrun due to the dominant factors are to minimize the risk, the executor before starting construction in the field should make an analysis of the concept, technical feasibility studies economically and report on the environmental impact, so that implementers can anticipate things that are not desirable. It should have professional and experienced supervisors. Implementing should be careful in placing the material and the material, but it should also give more attention to the surrounding society. There one way by recruiting the workers and security personnel from the society about the project. It should be done cycles of planning-control-correction continuously, so due to irregularities it can be minimized and great difficulty to achieve project goals can be avoided and then should do a comparative study to determine the source of funding. 


\section{References}

Arikunto S. 2006. Research Procedures A Practical Approach. Ed Revision VI, Publisher PT Rineka Cipta, Jakarta.

Asiyanto. 2009. Risk Management for Contractors. First edition. Publisher Pradnya Paramita. Jakarta

Dimyati H. and Nurjaman K. 2014. Project management. Pustaka Setia. Bandung.

Donald R. Cooper \& Pamela S. Schindler, 2006, "Bussines Research Methods", 9th edition. McGraw-Hill International Edition.

Ervianto, I., and Wulfram. 2005. Construction Project Management. Revised edition. C.V Andi Offset. Yogyakarta.

Husen, Ibrar. 2008. Project management.. Andy. Serpong.

Riduwan. 2003. Measurement Scale of Research Variables. Alfabeta. Bandung

Santosa. Budi. 2009. Project management. Graha IImu. Surabaya.

Sugiono. 2011. Educational Research Methods (Quantitative Approach, Qualitative, and R\&D); Alfabeta. Bandung.

Syahroni, Afnan. 2006. Identification of Factors Contributing Swelling Costs On Private Housing Project in Malang. Malang State University. Malang.

Umar, Husen. 2008. Business Research Methods. Jakarta: PT Gramedia Pustaka 